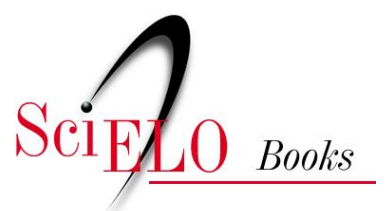

\title{
Fatores exóticos
}

\author{
Capistrano de Abreu
}

\section{SciELO Books / SciELO Livros / SciELO Libros}

ABREU, C. Fatores exóticos. In: Capítulos da história colonial [online]. Rio de Janeiro: Centro Edelstein de Pesquisa Social, 2009. pp. 12-17. ISBN: 978-85-7982-071-7.

https://doi.org/10.7476/9788579820717.0002.

\section{(8) Poviucio}

This work is free of known copyright restrictions. http://creativecommons.org/publicdomain/mark/1.0/

Este trabalho está livre de restrições de direito de autor e/ou de direitos conexos conhecidas.

http://creativecommons.org/publicdomain/mark/1.0/

Esta obra está libre de restricciones conocidas de derechos autorales. http://creativecommons.org/publicdomain/mark/1.0/ 


\section{FATORES EXÓTICOS}

Ao começar o século XVI, Portugal labutava na transição da idade média para a era moderna. Coexistiam em seu seio duas sociedades completas, com sua hierarquia, sua legislação e seus tribunais; mas a sociedade civil não professava mais a superioridade transcendente nem se sujeitava à dependência absoluta da Igreja, despida agora de muitas de suas históricas prerrogativas, obrigada a reduzir muitas de suas pretensões.

O Estado reconhecia e acatava as leis da Igreja, executava as sentenças de seus tribunais, declarava-se incompetente em quaisquer litígios debatidos entre clérigos, só punia um eclesiástico se, depois de degradado, era-lhe entregue por seus superiores ordinários, respeitava o direito de asilo nos templos e mosteiros para os criminosos cujas penas eram de sangue, abstinha-se de cobrar impostos do clero.

A Igreja dominava soberana pelo batismo, tão necessário à vida civil como à salvação da alma; pelo casamento, que podia permitir, sustar ou anular com impedimentos dirimentes; pelos sacramentos, distribuídos através da existência inteira; pela excomunhão, que incapacitava para todos eles; pelo interdito, que separava comunidades inteiras da comunicação dos santos; pela morte, permitindo ou negando sufrágios, deixando que o cadáver descansasse em lugar sagrado junto aos irmãos ou apodrecesse nos monturos em companhia dos bichos; dominava pelo ensino, limitando e definindo as crenças, extremando o que se podia do que não era lícito aprender ou ensinar.

Contra ela, na esfera estreita ainda em que firmara sua competência, depois de lutas com o papado e com o clero indígena, o Estado empregava o placet para os documentos emanados do sólio pontifício, os juízes da coroa para resguardar certos órgãos essenciais ao exercício normal da soberania plena, as leis de amortização para limitar as aquisições prediais, as temporaridades para abolir certas resistências. Em compensação, repartia sua jurisdição com o outro poder em casos por isso chamados mixti fori, prestava o braço secular para executar, até com morte violenta, os condenados pelo juízo eclesiástico, duramente castigava certos atos só porque a Igreja os considerava pecaminosos; em suma, o mesmo que hoje os interesses econômicos ou fiscais, pesavam então inspirações religiosas e considerações eclesiásticas.

Apesar de tudo ocorriam frequentes atritos entre a Igreja e o Estado, aquela disposta a abrir o menos possível mão de suas atribuições antigas, este conquistando ou assumindo sempre novas faculdades, para arcar com os problemas crescentes, legados onerosos do regime medieval, exigências inadiáveis de uma situação transformada pelo comércio fortalecido, pelas comunicações amiudadas, pela indústria renascente, pela renovação intelectual, pela circulação metálica em luta contra a economia naturista, rasgando horizontes mundiais.

Como o papa, cabeça da sociedade religiosa, o rei tornara-se o sujeito jurídico da sociedade civil: na qualidade de senhor absoluto, seus poderes não admitiam fronteiras definíveis, invocados como um princípio de equidade superior, como remédio a casos excepcionais, graves e imprevistos. De outros poderes suscetíveis de definição, podia fazer uso mais ou menos completo, e aliená-los em parte.

Era direito real bater moeda, criar capitães na terra e no mar, fazer oficiais de justiça, do ínfimo ao pino da carreira, declarar guerra, chamando o povo às armas com os mantimentos necessários. Para seu serviço el-rei tomava carros, bestas e navios dos súditos; pertenciam-lhe as estradas e as vias públicas, os rios navegáveis, os direitos de passagens de rios, os portos de mar com as portagens neles pagas, as ilhas adjacentes ao Reino, as rendas das pescarias, das marinhas, do sal, as minas de ouro, prata e quaisquer outros metais, os bens sem dono, os dos malfeitores de certos crimes. Nele se concentrava toda a faculdade legislativa: os votos das Cortes só valiam com o seu assenso e enquanto lhe aprazia, pois as disposições mais precisas podia dispensar, especificando-as; juízes e tribunais eram delegações do trono.

Abaixo do rei estava a nobreza, numerosa em famílias como nas distinções que separavam umas de outras, compreendendo desde os senhores donatários, com honras, coutos e jurisdição, e os grão-mestres das ordens militares, cujo mestrado o rei houve por bem afinal assumir, até simples cavaleiros e escudeiros. Seu poderio fora grande; agora contentavase com o monopólio dos cargos públicos, com o papel saliente nos tempos de guerra ou nos conselhos da coroa, com a situação privilegiada nas questões penais, em que o título de nobre defendia dos tormentos ou 
acarretava diminuição de pena. A nobreza não era uma casta exclusiva; davam para ela várias portas, entre as quais a das letras.

Abaixo da nobreza acampava o povo, a grande massa da nação, sem direitos pessoais, apenas defendidos seus filhos por pessoas morais a que se acostavam, lavradores, mecânicos, mercadores; os de mor qualidade chamavam-se homens bons, e reuniam-se em câmaras municipais, órgãos de administração local, cuja importância, então e sempre somenos, nunca pesou decisivamente em lances momentosos, nem no Reino, nem aqui, apesar dos esforços de escritores nossos contemporâneos, iludidos pelas aparências fugazes ou cegados por ideias preconcebidas.

Abundavam pessoas morais a que o povo se podia filiar corporações limitadas como as de moedeiros e bombardeiros, coletividades maiores como os cidadãos do Porto. Os privilégios inerentes a estes foram outorgados a várias cidades do Brasil, Maranhão, Bahia, Rio e São Paulo, pelo menos; pelo que encerram, dão bem a ideia de direitos regateados a quem tinha apenas para socorrer-se a mera qualidade de ser humano.

A estes felizes cidadãos do Porto concedeu dom João II: que não fossem metidos a tormentos por nenhuns malefícios que tivessem feito, cometido e cometessem e fizessem daí por diante, salvos nos feitos e daquelas qualidades e nos modos em que o devem ser e são os fidalgos do reino e senhores; que não pudessem ser presos por nenhum crime, somente sobre suas menagens e assim como o são e devem ser os fidalgos; que pudessem trazer e trouxessem por todos os seu reinos e senhorios quais e quantas armas lhes aprouvesse de noite e de dia, assim ofensivas como defensivas; que não pousassem com eles nem lhes tomassem suas casas de moradas, adegas, nem cavalariças, nem suas bestas de sela, nem outra nenhuma coisa de seu contra suas vontades e lhes catassem e guardassem muito inteiramente suas casas, e houvessem com elas e fora delas todas as liberdades que antigamente haviam os infanções e ricos homens; que os serviçais agrícolas só fossem à guerra com os patrões. Abaixo do terceiro estado havia ainda os servos, escravos, etc., etc., cujo direito único cifravase em poderem, dadas circunstâncias favoráveis, passar à classe imediatamente superior, pois, conquanto rentes as separações, as classes nunca se transformaram em castas. Os três braços do clero, da nobreza e do povo, convocados em ocasiões solenes e a intervalos arbitrários, constituiram as Cortes. Meramente consultivas, ou por igual deliberativas?
Liquidem entre si este ponto os eruditos de além-mar; fora de dúvida só valeram enquanto os reis consideraram reinar como um ofício e precisaram de recursos pecuniários para os quais não eram suficientes os copiosos direitos reais.

A prosperidade e o povoamento do Brasil provaram fatais a esta venerável instituição. Por uma coincidência nada fortuita, reuniram-se as últimas cortes em 1697, quando o ouro das Gerais começava a deslumbrar o mundo, e só reviveram com a revolução francesa, as guerras napoleônicas e a independência real do Brasil, depois de trasladada para aqui a sede da monarquia portuguesa.

Em 1527 a soma total dos fogos em todo o Reino andava por duzentos e oitenta mil quinhentos e vinte e oito; dando a cada um destes números de quatro indivíduos, a população do Reino seria naquele ano de um milhão e cento e vinte dois mil cento e doze almas. Com este pessoal exíguo, que não bastava para enchê-lo, ia Portugal povoar o mundo. Como consegui-lo em atirar-se à mestiçagem?

A agricultura estava atrasada no Reino; Damião Góis, explicando em 1541 à opinião letrada da Europa a razão dos seus atrasos em Portugal e Espanha, afirma ser a fertilidade espontânea do solo tamanha que a maior parte do ano os escravos e os homens pobres se podem sustentar lautamente de frutos silvestres, mel e ervas, o que os faz pouco propensos ao trabalho agrícola.

Alguns traços tomados ao livro de Costa Lobo mostrarão o caráter dominante do povo ao começar a era dos descobrimentos.

O português do século XV era fragueiro, abstêmio, de imaginação ardente, propenso ao misticismo, caráter independente, não constrangido pela disciplina ou contrafeito pela convenção; o seu falar era livre, não conhecia rebuços nem eufemismos de linguagem.

A têmpera era rija, o coração duro. As cominações penais não conheciam piedade. A morte expiava crimes tais como o furto do valor de um marco de prata. Ao falsificador de moeda infligia-se a morte pelo fogo, e o confisco de todos os bens.

Com a rudeza de costumes que assinala aqueles tempos, a segurança da própria pessoa, família e haveres, dependia em grande parte da força e 
energia individual; daí frequentes homizios, agressões, feridos e mortes que habituavam à contemplação da violência e da dor, infligida ou recebida. $\mathrm{O}$ espetáculo de penar não repugnava, porque ninguém tinha em muita conta o padecimento físico. Cruezas que hoje denotariam a vileza de um caráter perverso não tinham nesses tempos semelhante significação. $\mathrm{O}$ mal que elas causavam não se reputava demasia, todos estavam sujeitos a padecê-lo. Mas se a dor física ou moral alcançava molificar a rigeza da índole inacostumada à paciência e à reflexão ou se a paixão a inflamava, então o sentimento irrompia em clamores, prantos e contorsões, semelhando os meneios da demência furiosa.

À dureza da têmpera correspondia extensamente um aspecto agreste, a força muscular era tida em grande apreço. Cercear com um revés de montante uma perna de boi por meia coxa ou decepar-lhe quase todo o pescoço eram feitos dignos de recordação histórica.

Ao português estranho ao continente cumpre juntar o negro, igualmente alienígena. A importação começou desde o estabelecimento das capitanias e avultou nos séculos seguintes, primeiro por causa da cultura da cana, mais tarde por causa do fumo, das minas, do algodão e do café. Depois da supressão do tráfico em 1850, o café provocou deslocações consideráveis na distribuição interna; o mesmo efeito produziu a abolição.

Os primeiros negros vieram da costa ocidental, e pertencem geralmente ao grupo banto; mais tarde vieram de Moçambique. Sua organização robusta, sua resistência ao trabalho indicaram-nos para as rudes labutas que o indígena não tolerava. Destinados para a lavoura, penetraram na vida doméstica dos senhores pela ama de leite e pela mucama, e tornaram-se indispensáveis pela sua índole carinhosa. A mestiçagem com o elemento africano, ao contrário da mestiçagem com o americano, era vista com certa aversão, e inabilitava para certos postos. Os mulatos não podiam receber as ordens sacras, por exemplo: daí o desejo comum de ter um padre na família, para provar limpeza de sangue. Com o tempo os mulatos souberam melhorar de posição e por fim impor-se à sociedade. Quando reuniam a audácia ao talento e à fortuna alcançaram altas posições.

O negro trouxe uma nota alegre ao lado do português taciturno e do índio sorumbático. As suas danças lascivas, toleradas a princípio, tornaramse instituição nacional; suas feitiçarias e crenças propagaram-se fora das senzalas. As mulatas encontraram apreciadores de seus desgarres e foram verdadeiras rainhas. O Brasil é inferno dos negros, purgatório dos brancos, paraíso dos mulatos, resumiu em 1711 o benemérito Antonil. 